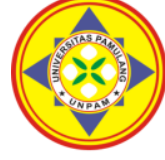

\title{
PENGARUH LOKASI DAN HARGA TERHADAP KEPUTUSAN PEMBELIAN PADA APARTMENT BAILEY'S CITY DI CIPUTAT
}

\author{
${ }^{1 *}$ Kiki Dwi Wijayanti, ${ }^{2}$ Komarudin, ${ }^{3}$ Sinta Sulistiani \\ Universitas Pamulang, Tangerang Selatan, Banten, Indonesia \\ *dosen02247@unpam.ac.id
}

\begin{abstract}
Abstrak
Penelitian ini bertujuan untuk mengetahui pengaruh lokasi dan harga terhadap keputusan pembelian pada Apartment Bailey's City di Ciputat. Metode yang digunakan adalah explanatory research dengan teknik analisis menggunakan analisis statistik dengan pengujian regresi, korelasi, determinasi dan uji hipotesis. Hasil penelitian ini lokasi berpengaruh signifikan terhadap keputusan pembelian sebesar 41,5\%, uji hipotesis diperoleh $t$ hitung $>t$ tabel atau $(7,994>1,987)$. Harga berpengaruh signifikan terhadap keputusan pembelian sebesar $50,2 \%$, uji hipotesis diperoleh $\mathrm{t}$ hitung $>\mathrm{t}$ tabel atau $(9,518>1,987)$. Lokasi dan harga secara simultan berpengaruh signifikan terhadap keputusan pembelian dengan persamaan regresi $Y=10,545+0,266 \mathrm{X} 1+0,480 \mathrm{X} 2$ dan kontribusi pengaruh sebesar 55,1\%, uji hipotesis diperoleh F hitung > F tabel atau $(54,696>2,710)$.
\end{abstract}

Kata Kunci: Lokasi, Harga, Keputusan Pembelian.

\section{Abstract}

This study aims to determine the effect of location and price on purchasing decisions at Bailey's City Apartment in Ciputat. The method used is explanatory research with analytical techniques using statistical analysis with regression, correlation, determination and hypothesis testing. The results of this study that location has a significant effect on purchasing decisions by $41.5 \%$, hypothesis testing is obtained $t$ count $>t$ table or $(7,994$ $>1,987)$. Price has a significant effect on purchasing decisions by $50.2 \%$, hypothesis testing is obtained $t$ count $>$ $t$ table or $(9.518>1.987)$. Location and price simultaneously have a significant effect on purchasing decisions with the regression equation $Y=10.545+0.266 \mathrm{X} 1+0.480 \mathrm{X} 2$ and the contribution of the influence is $55.1 \%$, hypothesis testing is obtained F count $>$ F table or $(54.696>2.710)$.

Keywords: Location, Price, Purchase Decision.

\section{PENDAHULUAN}

Zaman semakin berkembang dan peradaban manusia pun semakin berkembang dari waktu ke waktu menyebabkan kebutuhan akan hunian yang mulanya tidak begitu penting, menjadi salah satu kebutuhan pokok manusia yang harus dipenuhi disamping pendidikan dan kesehatan. Melihat perkembangan ini maka usaha dalam bidang properti (perumahan atau apartemen) menjadi terbuka lebar dan berkembang pesat. Hal ini ditandai dengan semakin banyaknya perusahaan yang mengelola bisnis properti.

Gapura Prima Group merupakan perusahaan yang bergerak pada usaha bisnis properti. Produk yang di pasarkan adalah apartemen atau hunian vertikal sebagai tempat tinggal maupun investasi yang dibutuhkan oleh semua orang. Artinya, kebutuhan terhadap produk tersebut tidak pernah berhenti (repeat business) seiring meningkatnya angka kelahiran dan bertambahnya jumlah penduduk serta keterbatasannya lahan untuk menciptakan hunian dalam jumlah yang banyak. Oleh sebab itu Gapura Prima Group mencoba membuat hunian dengan jumlah 1.100 hunian dengan luas lahan 1 Hektar terdiri dari 2 tower dengan konsep hunian lengkap di Ciputat dengan nama Apartment Bailey's City mencoba menciptakan satu hunian vertikal berkelas dengan harga terjangkau dengan fasilitasfasilitas seperti, Retail / Kios, Mini Market, 
Sekolah, Kolam Renang dan Taman, serta memiliki gedung parkir kendaraan di basement. Dengan nilai investasi 1,2 Triliun Gapura Prima Group mencoba memberikan satu hal yang berbeda dari apartmenapartmen yang ada di Ciputat. Adapun gambar lokasi Apartemen Bailey's City yaitu sebagai berikut :

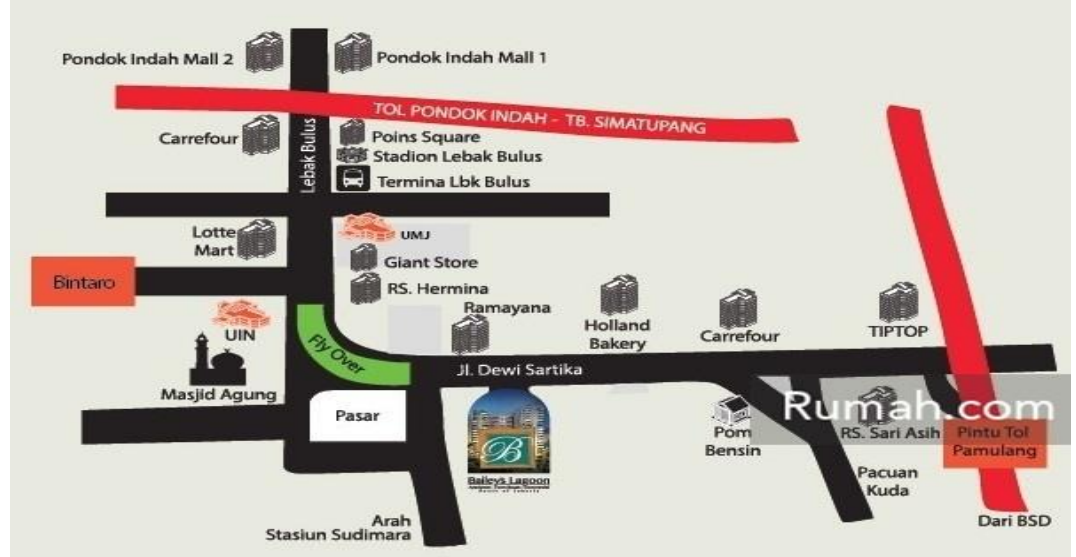

Sumber: www.rumah.com

Gambar 1. Lokasi Apartemen Bailey's City Ciputat

Survey yang dilakukan oleh www.rumah.com memaparkan bahwa terdapat sebanyak tiga hal menjadi faktor utama pembelian properti yang dilakukan oleh warga Indonesia, yaitu dari lokasi properti, harga yang ditawarkan oleh pengembang, dan potensi properti tersebut untuk bisa disewakan kembali (investasi).

Faktor lokasi menjadi faktor yang utama antara lain karna tingkat kemacetan yang semakin hari semakin meningkat di Jakarta, sehingga membuat masyarakat mencari akses alternatif untuk melakukan aktivitasnya. Tidak hanya kemacetan, kedekatan dengan fasilitas-fasilitas umum seperti fasilitas kesehatan, pendidikan, pusat perbelanjaan, tempat hiburan, jalan tol dan pusat bisnis juga menjadi bahan pertimbangan konsumen. Semakin dekat dengan fasilitas umum yang akan mempermudah konsumen dalam memutuskan untuk membeli properti tersebut. Pemilihan lokasi mempunyai fungsi yang strategis karena dapat ikut

Tabel 1. Data Keluhan Pembeli Apartemen Bailey's City Periode Januari-Juni Tahun 2018

\begin{tabular}{|l|c|c|c|}
\hline \multicolumn{1}{|c|}{ Jenis Keluhan } & April & Mei & Juni \\
\hline $\begin{array}{l}\text { Lokasi Apartemen yang berdekatan dengan pasar } \\
\text { tradisional yang menimbulkan aroma tidak sedap } \\
\text { (Bau) }\end{array}$ & 10 & 3 & 2 \\
\hline $\begin{array}{l}\text { Banyaknya kepadatan kendaraan yang melewati } \\
\text { jalur menuju apartemen (Macet) }\end{array}$ & 2 & 4 & 7 \\
\hline Lokasi menuju Apartemen sering terjadi banjir & 6 & 9 & 3 \\
\hline TOTAL & $\mathbf{1 8}$ & $\mathbf{1 5}$ & $\mathbf{1 2}$ \\
\hline
\end{tabular}

Sumber: Apartemen Bailey's City 2019. menentukan tercapainya tujuan badan usaha. Lokasi adalah mengacu kepada berbagai aktivitas pemasaran yang berusaha memperlancar dan mempermudah penyampaian atau penyaluran barang dan jasa dari produsen kepada konsumen, Tjiptono (2015:345). Sedangkan menurut Lupiyohadi Lupiyoadi (2013:157) lokasi adalah keputusan yang dibuat perusahaan berkaitan dengan dimana operasi dan stafnya akan ditempatkan. Pentingnya lokasi bagi perusahaan jasa bergantung pada jenis dan derajat interkasi yang terlibat. Lokasi merupakan suatu tempat dimana hasil produk perusahaan berada. Lokasi akan ikut berperan dalam menentukan kesuksesan dan pencapaian suatu usaha karena lokasi akan berpengaruh terhadap besarnya pasar potensial yang dapat dicapai oleh suatu perusahaan. Berikut beberapa keluhan yang keterkaitan dengan lokasi Apartemen Bailey's City: 
Jika dilihat dari peta lokasi dan keluhan pembeli, maka letak Apartemen Bailey's City memiliki lokasi yang dekat dengan pasar tradisonal dimana pasar tradisional identik dengan kotor dan bau sampah. Dan lokasi juga sering terjadi kepadatan kendaraan yang sudah menjadi rutinitas setiap harinya. Hal ini juga yang menyebabkan banyak konsumen yang beralih ke apartemen yang lain. Selain itu juga sudah banyak apartemen lain yang berdiri dekat dengan Apartment Bailey's City seperti City Light, Green Lake View, Ciputat Resort dan lainya. Lokasi Juga merupakan saluran distribusi yaitu jalur yang dipakai untuk perpindahan produk dari produsen ke konsumen. Lokasi adalah keputusan yang dibuat perusahaan berkaitan dengan dimana operasi dan stafnya akan ditempatkan Lupiyohadi Lupiyoadi (2013:157). Sedangkan menurut Heizer dan Render (2015:128) Lokasi juga pendorong biaya dan pendapatan, maka lokasi seringkali memiliki kekuasaan untuk membuat strategi bisnis perusahaan. Lokasi yang strategis bertujuan untuk memaksimalkan keuntungan perusahaan.

Gapura Prima Group selaku developer dari Apartemen Bailey's City merupakan salah satu developer yang memiliki nama dalam bisnis properti. Seiring bertambahnya proyek yang pernah diselesaikan dan yang sedang dikembangkan oleh Gapura Prima Group, tingkat kepercayaan konsumen juga semakin meningkat. Tingkat kepercayaan konsumen memiliki bagian yang cukup

Tabel 2. Harga Apartemen Bailey's penting terhadap pengambilan keputusan pembelian suatu produk. Semakin tinggi tingkat kepercayaan konsumen, semakin besar juga kepercayaan konsumen dalam mengambil keputusan pembelian properti tersebut.

Harga juga menjadi salah satu faktor utama lainnya dalam hal ini dinilai penting terutama karena saat ini tingkat harga baik dalam hal residensial maupun unit perkantoran juga semakin mahal. Harga merupakan sejumlah uang yang ditagihkan atas suatu produk dan jasa atau jumlah dari nilai yang ditukar para pelanggan untuk memperoleh menfaat-manfaat karena memiliki atau menggunakan produk atau jasa tersebut, Kotler dan Amstrong (2011:345). Sedangkan menurut Philip Kotler (2012:132) adalah jumlah uang yang harus dibayar pelanggan untuk suatu produk. Mengartikan bahwa harga merupakan sejumlah uang uang dibutuhkan untuk sejumlah kombinasi dari barang beserta pelayanannya. Lebih luas lagi harga merupakan jumlah nilai yang diberikan pelanggan untuk mendapatkan keuntungan dari memiliki atau menggunakan suatu produk atau jasa. Dalam keputusan pembelian suatu produk, peran harga sangatlah penting. Karena itu, perusahaan harus mampu menciptakan strategi penentuan harga yang tidak hanya memberi keuntungan bagi perusahaan, namun juga memuaskan pelanggannya. Adapun harga apartemen yang berlaku priode Januari - Juni 2018 sebagai berikut :

\begin{tabular}{|c|c|c|c|c|}
\hline No & Tipe Unit & $\begin{array}{c}\text { Harga Apartemen } \\
\text { Bailey's City } \\
(\mathrm{Rp})\end{array}$ & $\begin{array}{c}\text { Harga } \\
\text { Apartemen } \\
\text { Green Lake } \\
\text { View } \\
(\mathrm{Rp})\end{array}$ & $\begin{array}{c}\text { Harga } \\
\text { Apartemen } \\
\text { Ciputat Resort } \\
(\mathrm{Rp})\end{array}$ \\
\hline 1. & Studio & 389.934 .000 & 340.500 .000 & 327.400 .000 \\
\hline 2. & 1 Bed Room & 509.490 .000 & 489.750 .000 & - \\
\hline 3. & 2 Bed Room & 821.178 .000 & 797.125 .000 & 753.500 .000 \\
\hline
\end{tabular}

Sumber: Apartemen Bailey's City.

Jika dilihat dari harga sudah lumrah apabila produk dengan harga murah lebih diminati dari pada produk dengan harga yang lebih mahal. Bukan berarti produk mahal tidak diminati sama sekali, namun dengan tingginya harga produk tersebut juga akan membawakan rasa bangga tersendiri bagi konsumen karena hal itu 
secara tidak langsung mengisyaratkan tingginya kemampuan daya beli konsumen. Jika dilihat dari tabel 1.2 maka harga Apartemen Bailey's City lebih mahal dari harga pesaing. Untuk tipe studio harganya Rp 389.934.000,- sedangkan harga pesaing kurang dari $(<)$ Rp. 350.000.000,-Berdasarkan harga tersebut maka banyak konsumen yang berpikir untuk melakukan pembelian apartemen tersebut. Dimana keputusan pembelian merupakan kegiatan individu yang secara langsung terlibat dalam pengambilan keputusan untuk melakukan pembelian terhadap produk yang ditawarkan oleh penjual. keputusan

Tabel 3. Data Penjualan Apartemen Bailey's konsumen adalah motif atau dorongan yang timbul terhadap sesuatu dimana pembeli melakukan pembelian disebabkan adanya kebutuhan dan keinginan. Menurut Kotler dan Amstrong (2012:149) menyatakan bahwa keputusan pembelian adalah tahap proses keputusan dimana konsumen secara aktual melakukan pembelian produk. Konsumen sebagai pelaku utama dalam proses pembelian selalu menjadi perhatian produsen. Untuk mengetahui data penjualan Apartemen Bailey's City Ciputat dapat dilihat dari total penjualan periode bulan Januari - Juni 2018 sebagai berikut:

\begin{tabular}{|c|c|c|c|c|}
\hline \multirow[b]{2}{*}{ Bulan } & \multicolumn{2}{|c|}{ Penjualan (Unit } & \multicolumn{2}{|c|}{ Jumlah Konsumen } \\
\hline & $\begin{array}{c}\text { Target } \\
\text { Penjualan }\end{array}$ & $\begin{array}{c}\text { Realisasi } \\
\text { Penjualan }\end{array}$ & $\begin{array}{c}\text { Target } \\
\text { Konsumen }\end{array}$ & $\begin{array}{c}\text { Realisasi } \\
\text { Konsumen }\end{array}$ \\
\hline 2014 & 125 & 115 & 200 & 126 \\
\hline 2015 & 175 & 320 & 250 & 382 \\
\hline 2016 & 225 & 295 & 300 & 334 \\
\hline 2017 & 275 & 112 & 450 & 132 \\
\hline 2018 & 300 & 86 & 500 & 120 \\
\hline Rata-rata & 220 & 185 & 340 & 218 \\
\hline
\end{tabular}

Sumber: Apartemen Bailey's City.

Berdasarkan data diatas terlihat bahwa penjualan Apartemen Bailey's City Ciputat mengalami tidak kestabilan dan cendrung menurun pada tahun 2017 sampai dengan 2018. Dari yang sudah ditargetkan dan realisasi yang ada sangat menurun. Kondisi yang terjadi tersebut disebabkan oleh adanya faktor-faktor yang mempengaruhi konsumen dalam melakukan keputusan pembelian Apartemen Bailey's City Ciputat, salah satunya semakin banyaknya kompetitor di wilayah Ciputat sehingga membuat penjualan Apartemen Bailey's City menurun. Berdasarkan denah lokasi dan tabel harga tersebut hal ini menandakan bahwa jumlah penjualan Apartmen Bailey's City Ciputat mengalami penurunan. Sehingga lokasi dan harga memiliki pengaruh terhadap keputusan pembelian konsumen pada Apartmen Bailey's City Ciputat.

Berdasarkan penjelasan diatas, maka penelitian ini berjudul "Pengaruh Lokasi Dan Harga Terhadap Keputusan Pembelian Pada Apartemen Bailey's.

\section{TINJAUAN PUSTAKA}

\section{Lokasi}

Yang dimaksud lokasi dalam penelitian ini adalah mengacu kepada berbagai aktivitas pemasaran yang berusaha memperlancar dan mempermudah penyampaian atau penyaluran barang dan jasa dari produsen kepada konsumen, Tjiptono (2015:345). Adapun indikator yang dapat digunakan meliputi: Akses, Visiabilitas, Lalu lintas, Tempat parkir yang luas, Ekspansi, Lingkungan.

\section{Harga}

Yang dimaksud harga dalam penelitian ini adalah sejumlah uang yang ditagihkan atas suatu produk dan jasa atau jumlah dari nilai yang ditukar para pelanggan untuk memperoleh menfaatmanfaat karena memiliki atau menggunakan produk atau jasa tersebut, Kotler dan Amstrong (2011:345). Adapun indikator yang dapat digunakan meliputi: Keterjangkauan 
harga, Kesesuaian harga dengan kualitas produk, Kesesuaian harga dengan manfaat, Harga sesuai kemampuan atau daya saing harga.

\section{Keputusan Pembelian}

Dalam penelitian ini yang dijadikan variabel dependen adalah "Keputusan pembelian yang diartikan sebagai tahap proses keputusan dimana konsumen secara aktual melakukan pembelian produk. Konsumen sebagai pelaku utama dalam proses pembelian selalu menjadi perhatian produsen", Kotler dan Amstrong (2012:149). Adapun indikator yang dapat digunakan meliputi: Pengenalan masalah, Pencarian informasi, Evaluasi alternatif, Keputusan pembelian, Prilaku setelah pembelian

\section{METODE}

Populasi dalam penelitian ini berjumlah 92 responden Apartment Bailey's City di Ciputat, Sampel dalam penelitian ini berjumlah 92 responden. Jenis penelitian yang dipakai adalah kuantitatif, dimana tujuannya adalah untuk mengetahui pengaruh antara variabel bebas terhadap variabel terikat baik parsial maupun simultan , Dalam menganalisis data digunakan uji instrumen, uji asumsi klasik, regresi, koefisien korelasi, koefisien determinasi dan uji hipotesis.

\section{HASIL DAN PEMBAHASAN}

\section{Analisis Deskriptif}

Pada pengujian ini digunakan untuk mengetahui skor minimum dan maksimum, mean score dan standar deviasi dari masing-masing variabel. Adapun hasilnya sebagai berikut:

Tabel 4. Hasil Analisis Descriptive Statistics

Descriptive Statistics

N $\quad$ Minimum Maximum Mean Std. Deviation

\begin{tabular}{|l|l|l|l|l|r|}
\hline Lokasi (X1) & 92 & 31 & 48 & 37.76 & 4.004 \\
\hline Harga (X2) & 92 & 31 & 46 & 37.88 & 3.667 \\
\hline Keputusan Pembelian (Y) & 92 & 32 & 46 & 38.77 & 3.505 \\
\hline Valid N (listwise) & 92 & & & & \\
\hline
\end{tabular}

Lokasi diperoleh varians minimum sebesar 31 dan varians maximum 48 dengan mean score sebesar 37,76 dengan standar deviasi 4,004 .

Harga diperoleh varians minimum sebesar 31 dan varians maximum 46 dengan mean score sebesar 37,88 dengan standar deviasi 3,667.

Keputusan pembelian diperoleh varians minimum sebesar 32 dan varians maximum 46 dengan mean score sebesar 38,77 dengan standar deviasi 3,505.

\section{Analisis Verifikatif.}

Pada analisis ini dimaksudkan untuk mengetahui pengaruh variabel independen terhadap variabel dependen. Adapun hasil pengujian sebagai berikut:

a. Analisis Regresi Linier Berganda

Uji regresi ini dimaksudkan untuk mengetahui perubahan variabel dependen jika variabel independen mengalami perubahan. Adapun hasil pengujiannya sebagai berikut:

Tabel 5. Hasil Pengujian Regresi Linier Berganda

\section{Coefficients $^{\mathrm{a}}$}

Unstandardized Coefficients

\begin{tabular}{llr|r|r|r|r}
\multicolumn{1}{l}{ Model } & \multicolumn{1}{c}{ B } & Std. Error & Beta & \multicolumn{1}{c}{$\mathrm{t}$} & \multicolumn{1}{c}{ Sig. } \\
\hline 1 & (Constant) & 10.545 & 2.710 & & 3.891 & .000 \\
\cline { 2 - 7 } & Lokasi (X1) & .266 & .085 & .304 & 3.142 & .002 \\
\hline Harga (X2) & .480 & .092 & .502 & 5.198 & .000 \\
\hline
\end{tabular}

a. Dependent Variable: Keputusan Pembelian (Y) 
Berdasarkan hasil pengujian pada tabel di atas, diperoleh persamaan regresi $\mathrm{Y}=10,545+$ 0,266X1 + 0,480X2. Dari persamaan tersebut dijelaskan sebagai berikut:

1) Konstanta sebesar 10,545 diartikan jika lokasi dan harga tidak ada, maka telah terdapat nilai keputusan pembelian sebesar 10,545 point.

2) Koefisien regresi lokasi sebesar 0,266, angka ini positif artinya setiap ada peningkatan lokasi sebesar 0,266 maka keputusan pembelian juga akan mengalami peningkatan sebesar 0,266 point.

Tabel 6. Hasil Pengujian Koefisien Korelasi Lokasi Terhadap Keputusan Pembelian.

Correlations $^{b}$

\begin{tabular}{|c|c|c|c|}
\hline & & Lokasi (X1) & $\begin{array}{c}\text { Keputusan } \\
\text { Pembelian (Y) }\end{array}$ \\
\hline \multirow[t]{2}{*}{$\overline{\text { Lokasi }(\mathrm{X} 1)}$} & Pearson Correlation & 1 & $.644^{* *}$ \\
\hline & Sig. (2-tailed) & & .000 \\
\hline \multirow{2}{*}{$\begin{array}{l}\text { Keputusan Pembelian } \\
\text { (Y) }\end{array}$} & Pearson Correlation & $.644^{* *}$ & 1 \\
\hline & Sig. (2-tailed) & .000 & \\
\hline
\end{tabular}

Berdasarkan hasil pengujian diperoleh nilai korelasi sebesar 0,644 artinya lokasi memiliki hubungan

Tabel 7. Hasil Pengujian Koefisien Korelasi Harga Terhadap Keputusan Pembelian. Correlations $^{b}$

\begin{tabular}{llr|r} 
& & \multicolumn{1}{|c}{$\begin{array}{c}\text { Keputusan } \\
\text { Pembelian (Y) }\end{array}$} \\
\hline Harga (X2) & Pearson Correlation & 1 & $.708^{* *}$ \\
\cline { 2 - 4 } & Sig. (2-tailed) & & .000 \\
\hline Keputusan Pembelian (Y) & Pearson Correlation & $.708^{* *}$ & 1 \\
\cline { 2 - 4 } & Sig. (2-tailed) & .000 & \\
\hline \multirow{2}{**}{. Correlation is significant at the 0.01 level (2-tailed). } & & \\
b. Listwise N=92 & & &
\end{tabular}

Berdasarkan hasil pengujian diperoleh nilai korelasi sebesar 0,708 artinya harga memiliki hubungan yang kuat terhadap keputusan pembelian.

Tabel 8. Hasil Pengujian Koefisien Korelasi Lokasi dan Harga secara simultan Terhadap Keputusan Pembelian. Model Summary

\begin{tabular}{l|r|rr|rr} 
Model & $\mathrm{R}$ & \multicolumn{2}{c|}{$\begin{array}{c}\text { Adjusted R } \\
\text { Square }\end{array}$} & \multicolumn{2}{c}{$\begin{array}{c}\text { Std. Error of the } \\
\text { Estimate }\end{array}$} \\
\hline 1 & $.743^{\mathrm{a}}$ & .551 & .541 & 2.374 \\
\hline a. Predictors: (Constant), Harga (X2), Lokasi (X1) & & &
\end{tabular}


Berdasarkan hasil pengujian diperoleh nilai korelasi sebesar 0,745 artinya lokasi dan harga secara simultan memiliki hubungan yang kuat terhadap keputusan pembelian. c. Analisis Koefisien Determinasi

Analisis koefisien determinasi dimaksudkan untuk mengetahui besarnya persentase pengaruh dari variabel independen terhadap variabel dependen baik secara parsial maupun simultan. Adapun hasil pengujian sebagai berikut:

Tabel 9. Hasil Pengujian Koefisien Determinasi Lokasi Terhadap Keputusan Pembelian.

Model Summary

\begin{tabular}{lr|r|r|rr} 
Model & & \multicolumn{2}{|c|}{$\begin{array}{c}\text { Adjusted R } \\
\text { Square }\end{array}$} & \multicolumn{2}{c}{$\begin{array}{c}\text { Std. Error of the } \\
\text { Estimate }\end{array}$} \\
\hline 1 & $\mathrm{R}$ & R Square & .409 & 2.695 \\
\hline
\end{tabular}

a. Predictors: (Constant), Lokasi (X1)

Berdasarkan hasil pengujian diperoleh nilai determinasi sebesar 0,415 artinya lokasi memiliki

kontribusi pengaruh sebesar $41,5 \%$ terhadap keputusan pembelian.

Tabel 10. Hasil Pengujian Koefisien Determinasi Harga Terhadap Keputusan pembelian.

Model Summary

\begin{tabular}{|c|c|c|c|c|}
\hline Model & $\mathrm{R}$ & R Square & $\begin{array}{l}\text { Adjusted R } \\
\text { Square }\end{array}$ & $\begin{array}{l}\text { Std. Error of the } \\
\text { Estimate }\end{array}$ \\
\hline 1 & $.708^{a}$ & .502 & .496 & 2.488 \\
\hline
\end{tabular}

Berdasarkan hasil pengujian kontribusi pengaruh sebesar 50,2\% diperoleh nilai determinasi sebesar 0,502 artinya harga memiliki terhadap keputusan pembelian.

Tabel 11. Hasil Pengujian Koefisien Determinasi Lokasi dan Harga Terhadap Keputusan pembelian.

Model Summary

\begin{tabular}{|c|c|c|c|c|}
\hline \multirow[b]{2}{*}{ Model } & & 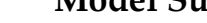 & & \\
\hline & $\mathrm{R}$ & R Square & $\begin{array}{c}\text { Adjusted R } \\
\text { Square }\end{array}$ & $\begin{array}{l}\text { Std. Error of the } \\
\text { Estimate }\end{array}$ \\
\hline 1 & $.743^{\mathrm{a}}$ & .551 & .541 & 2.374 \\
\hline
\end{tabular}

Berdasarkan hasil pengujian diperoleh nilai determinasi sebesar 0,551 artinya lokasi dan harga secara simultan memiliki kontribusi pengaruh sebesar $55,1 \%$ terhadap keputusan pembelian, sedangkan sisanya sebesar $44,9 \%$ dipengaruhi faktor lain. d. Uji Hipotesis

Uji hipotesis Parsial (Uji t)

Pengujian hipotesis dengan uji $t$ digunakan untuk mengetahui hipotesis parsial mana yang diterima. Hipotesis pertama: Terdapat pengaruh yang signifikan antara lokasi terhadap keputusan pembelian.

Tabel 12. Hasil Uji Hipotesis Lokasi Terhadap Keputusan pembelian.

\section{Coefficients ${ }^{\mathrm{a}}$}

\begin{tabular}{|c|c|c|c|c|c|c|}
\hline \multirow{2}{*}{\multicolumn{2}{|c|}{ Model }} & \multicolumn{2}{|c|}{$\begin{array}{c}\text { Unstandardized } \\
\text { Coefficients }\end{array}$} & \multirow{2}{*}{$\begin{array}{l}\text { Standardized } \\
\text { Coefficients } \\
\text { Beta }\end{array}$} & \multirow[b]{2}{*}{$\mathrm{t}$} & \multirow[b]{2}{*}{ Sig. } \\
\hline & & $\mathrm{B}$ & Std. Error & & & \\
\hline \multirow[t]{2}{*}{1} & (Constant) & 17.468 & 2.680 & & 6.519 & .000 \\
\hline & Lokasi (X1) & .564 & .071 & .644 & 7.994 & .000 \\
\hline
\end{tabular}

a. Dependent Variable: Keputusan Pembelian (Y) 
Berdasarkan hasil pengujian pada tabel di atas, diperoleh nilai $\mathrm{t}$ hitung $>\mathrm{t}$ tabel atau $(7,994>1,987)$, dengan demikian hipotesis pertama Tabel 13. Hasil Uji Hipotesis Harga Terhadap Keputusan pembelian. Coefficients ${ }^{\mathbf{a}}$ Unstandardized Coefficients

\begin{tabular}{|c|c|c|c|c|c|c|}
\hline \multirow{3}{*}{\multicolumn{2}{|c|}{ Model }} & \multicolumn{3}{|c|}{ Coefficients ${ }^{a}$} & \multirow[b]{3}{*}{$\mathrm{t}$} & \multirow[b]{3}{*}{ Sig. } \\
\hline & & \multicolumn{2}{|c|}{$\begin{array}{l}\text { Unstandardized } \\
\text { Coefficients }\end{array}$} & \multirow{2}{*}{$\begin{array}{c}\text { Standardized } \\
\text { Coefficients } \\
\text { Beta }\end{array}$} & & \\
\hline & & B & Std. Error & & & \\
\hline 1 & (Constant) & 13.125 & 2.707 & & 4.848 & .000 \\
\hline & Harga (X2) & .677 & .071 & .708 & 9.518 & .000 \\
\hline
\end{tabular}

a. Dependent Variable: Keputusan Pembelian (Y)

Berdasarkan hasil pengujian pada tabel di atas, diperoleh nilai $\mathrm{t}$ hitung $>\mathrm{t}$ tabel atau $(9,518>1,987)$, dengan demikian hipotesis kedua yang diajukan bahwa terdapat pengaruh yang signifikan atara harga terhadap keputusan pembelian diterima. yang diajukan bahwa terdapat pengaruh yang signifikan atara lokasi terhadap keputusan pembelian diterima.

\section{Uji Hipotesis Simultan (Uji F)}

Pengujian hipotesis dengan uji $\mathrm{F}$ digunakan untuk mengetahui hipotesis simultan yang mana yang diterima.

Hipotesis ketiga Terdapat pengaruh yang signifikan antara lokasi dan harga terhadap keputusan pembelian.

Tabel 14. Hasil Uji Hipotesis Lokasi dan Harga Terhadap Keputusan pembelian.

\begin{tabular}{|c|c|c|c|c|c|c|}
\hline \multicolumn{7}{|c|}{ ANOVA $^{\mathrm{a}}$} \\
\hline \multicolumn{2}{|c|}{ Model } & $\begin{array}{l}\text { Sum of } \\
\text { Squares }\end{array}$ & $\mathrm{df}$ & $\begin{array}{l}\text { Mean } \\
\text { Square }\end{array}$ & $\mathrm{F}$ & Sig. \\
\hline \multirow[t]{3}{*}{1} & Regression & 616.572 & 2 & 308.286 & 54.696 & $.000^{\mathrm{b}}$ \\
\hline & Residual & 501.635 & 89 & 5.636 & & \\
\hline & Total & 1118.207 & 91 & & & \\
\hline
\end{tabular}

a. Dependent Variable: Keputusan Pembelian (Y)

b. Predictors: (Constant), Harga (X2), Lokasi (X1)

Berdasarkan hasil pengujian pada tabel di atas, diperoleh nilai $\mathrm{F}$ hitung > F tabel atau $(54,696>2,710)$, dengan demikian hipotesis ketiga yang diajukan bahwa terdapat pengaruh yang signifikan atara lokasi dan harga terhadap keputusan pembelian diterima.

\section{PEMBAHASAN HASIL PENELITIAN}

1. Pengaruh Lokasi Terhadap Keputusan Pembelian

Lokasi berpengaruh signifikan terhadap keputusan pembelian dengan korelasi sebesar 0,644 atau memiliki hubungan yang kuat dengan kontribusi pengaruh sebesar $41,5 \%$. Pengujian hipotesis diperoleh nilai $\mathrm{t}$ hitung $>\mathrm{t}$ tabel atau $(7,994>1,987)$. Dengan demikian hipotesis pertama yang diajukan bahwa terdapat berpengaruh signifikan antara lokasi terhadap keputusan pembelian diterima.

\section{Pengaruh Harga Terhadap Keputusan Pembelian}

Harga berpengaruh signifikan terhadap keputusan pembelian dengan korelasi sebesar 0,708 atau memiliki hubungan yang kuat dengan kontribusi pengaruh sebesar 50,2\%. Pengujian hipotesis diperoleh nilai $\mathrm{t}$ hitung $>\mathrm{t}$ tabel atau $(9,518>1,987)$. Dengan demikian hipotesis kedua yang diajukan bahwa terdapat berpengaruh signifikan antara harga terhadap keputusan pembelian diterima. 


\section{Pengaruh Lokasi dan Harga Terhadap Keputusan Pembelian}

Lokasi dan harga berpengaruh signifikan terhadap keputusan pembelian dengan diperoleh persamaan regresi $Y=10,545+0,266 X 1+0,480 X 2$, nilai korelasi sebesar 0,745 atau memiliki hubungan yang kuat dengan kontribusi pengaruh sebesar $55,1 \%$ sedangkan sisanya sebesar $44,9 \%$ dipengaruhi faktor lain. Pengujian hipotesis diperoleh nilai $\mathrm{F}$ hitung $>$ F tabel atau $(54,696>2,710)$. Dengan demikian hipotesis ketiga yang diajukan bahwa terdapat berpengaruh signifikan antara lokasi dan harga terhadap keputusan pembelian diterima.

\section{PENUTUP}

\section{Kesimpulan}

1. Lokasi berpengaruh signifikan terhadap keputusan pembelian dengan kontribusi pengaruh sebesar $41,5 \%$. Uji hipotesis diperoleh nilai $\mathrm{t}$ hitung $>\mathrm{t}$ tabel atau $(7,994>1,987)$.

2. Harga berpengaruh signifikan terhadap keputusan pembelian dengan kontribusi pengaruh sebesar $50,2 \%$. Uji hipotesis diperoleh nilai $\mathrm{t}$ hitung $>\mathrm{t}$ tabel atau $(9,518>1,987)$.

3. Lokasi dan harga berpengaruh signifikan terhadap keputusan pembelian dengan kontribusi pengaruh sebesar 55,1\% sedangkan sisanya sebesar $44,9 \%$ dipengaruhi faktor lain. Uji hipotesis diperoleh nilai $\mathrm{F}$ hitung $>\mathrm{F}$ tabel atau $(54,696>2,710)$.

\section{Saran}

1. Variabel lokasi indikator yang paling lemah adalah lingkungan, maka perusahaan harus menjamin keamanan lingkungan mengingat keamanan dan kenyamanan lingkungan apartemen merupakan salah satu faktor penting dalam meningkatkan peminat konsumen untuk melakukan keputusan pembelian pada apartemen bailey's city.

2. Variabel harga indikator yang paling lemah adalah kesesuaian harga dengan kualitas produk. Untuk lebih baik lagi perusahaan harus mempertimbangkan kessuaian harga dengan kualitas bangunan mengingat harga dengan kualitas produk merupakan hal penting bagi konsumen dan dimana hal ini harus jadi perhatian bagi perusahaan untuk menwujudkan hal terpenting bagi konsumen untuk mengambil keputusan pembelian.

3. Variabel keputusan pembelian, indikator yang paling lemah adalah evaluasi alternatif. Untuk lebih baik lahi perusahaan harus memperbanyak alternatif pilihan mengingat keputusan pembelian membutuhkan perbandingan maupun evaluasi sebelumnya. Dalam keberhasilan perusahaan maka untuk lebih baik lagi perusahaan perlu memperhatikan hal-hal penting orientasi konsumen dalam mengambil keputusan pembelian agar dapat tercapai tujuan perusahaan secara optimal.

4. Kontibusi pengaruh lokasi dan harga secara simultan terhadap keputusan pembelian sebesar 55,1\%, nilai ini masih bisa ditingkatkan dengan cara memperhatikan kekurangankekurangan yang sangat penting bagi konsumen. Dengan adanya stuktur organisasi yang sudah ada seharusnya ditingkatkan secara maksimal agar tujuan perusahaan dapat segera tercapai. Oleh karenanya disarankan kepada penelitian berikutnya agar melakukan penelitian yang relevan dengan cara memperbaiki indikator yang masih tidak baik atau dengan menambah indikator pertanyaan dan jumlah responden penelitian sehingga akan dapat lebih diketahui variabel yang paling memberikan kontribusi positif bagi perusahaan.

\section{DAFTAR PUSTAKA}

Affandi, A., Sarwani, A. S., Erlangga, H., Siagian, A. O., Purwanto, A., Effendy, A. A., ... \& Wahyitno, C. D. M. (2020). Optimization of MSMEs Empowerment in Facing Competition in the Global Market during the COVID-19 Pandemic Time. Systematic Reviews in Pharmacy, 11(11), 1506-1515. 
Akbar, I. R., Erlangga, H., Jasmani, J., Oktarini, R., \& Yusuf, A. (2021). Pengaruh Citra Merek Terhadap Keputusan Pembelian Sepatu Nike Pada Mahasiswa Universitas Pamulang. Jurnal Ilmah PERKUSI, 1(1), 94-100.

Alma, B (2011). "Manajemen Pemasaran dan Pemasaran Jasa". Cetakan kelima. Edisi Revisi. Bandung: Alfabeta.

Arikunto, (2013). "Prosedur Penelitian Suatu Pendekatan Praktik". Jakarta: Rineka Cipta.

Assauri, (2013). "Manajemen Pemasaran". Jakarta: Rajawali Pers.

Aswin Rakasiwi, Jurnal Penelitian \& Kajian Ilmiah, ISSN (2085-2215), Vol. 14, No.3, Juli (2016), "Pengaruh Kualitas Produk, Harga Dan Lokasi Terhadap Keputusan Pembelian Batu Mulia Pada Toko Safhira Galeri Surakarta".

Dharmayuni, L., Sunarsi, D., Sembiring, E. S. K., Satata, S., Bahrudin, U., Erlangga, H., ... \& Salam, A. F. (2021). Effect of Distribution Cost and Promotion Cost on Tyre Industries Sales Performance. Annals of the Romanian Society for Cell Biology, 12672-12684.

Erlangga, H. (2021). Effect Of Digital Marketing And Social Media On Purchase Intention Of Smes Food Products. Turkish Journal of Computer and Mathematics Education (TURCOMAT), 12(3), 3672-3678.

Ghozali, Imam (2014). "Structural Equation Modeling Metode Alternatif dengan Partial Least Square (PLS)". Edisi 4. Semarang: Badan Penerbit Diponegoro.

Haque, M. G., Nurjaya, N., Affandi, A., Erlangga, H., \& Sunarsi, D. (2021). Micro Financial Sharia Non-bank Strategic Analysis: a Study at BMT Beringharjo, Yogyakarta. Budapest International Research and Critics Institute (BIRCI-Journal): Humanities and Social Sciences, 4(2), 1677-1686.

Hariman Syaleh, Jurnal Ekonomi, ISSN (2597-5234), Vol. 1, No.1, Desember
(2017), “Pengaruh Kualitas Produk, Harga, Promosi Dan Lokasi Terhadap Keputusan Pembelian Sepeda Motor Yamaha Pada CV Tjahaja Baru Bukit Tinggi".

Hindarsah, I. (2021). The Influence of Service Quality, Emotional Marketing and Spiritual Marketing On Customer Satisfaction. Turkish Journal of Computer and Mathematics Education (TURCOMAT), 12(3), 3685-3689.

Kotler and Keller (2012). "Marketing Metodologi Penelitian Untuk Bisnis". Edisi 4. Jakarta: Erlangga.

Lupiyoadi, Rambat (2013). "Manajemen Pemasaran Jasa". Jakarta: Salemba Empat.

Nurjaya, N., Erlangga, H., Jasmani, J., Sunarsi, D., Rifuddin, B., \& Mujahidin, M. (2020). Pengaruh Store Atmosphere Terhadap Keputusan Pembelian Konsumen Pada Starbucks Di Wilayah Cianjur. Jurnal Ekonomi Efektif, 2(4), 637-643.

Setiawati, N. P. A., Sunarsi, D., Nurjaya, S., Manan, A., Nurhadi, A., Erlangga, H., ... \& Purwanto, A. (2021). Effect of Technology Acceptance Factors, Website Service Quality and Specific Holdup Cost on Customer Loyalty: A Study in Marketing Departement of Packaging Industry. Annals of the Romanian Society for Cell Biology, 12685-12697.

Situmorang (2013). "Analisis Efisiensi Pemasaran Ubi Kayu di Provinsi Lampung". Jurnal Ilmu-Ilmu Agribisnis, Vol 1 (1): 80-86. Lampung. Swastha, B dan Handoko, T Hani (2013). "Manajemen Pemasaran Analisis Perilaku Konsumen". Edisi I. Yogyakarta.

Yulistiana, I., Dewi, R. V., Mas' adi, M., Sunarsi, D., \& Erlangga, H. (2021). Did Brand Perceived Quality, Image Product And Place Convenience Influence Customer Loyalty Through Unique Value Proposition?. Journal of Contemporary Issues in Business and Government, 27(1), 2854-2867. 